\title{
Enjoying A Good Story: Why We Use Children's Literature When Teaching Adults
}

\author{
Nancy K. Freeman • Stephanie Feeney • \\ Eva Moravcik
}

Published online: 15 December 2010

(C) Springer Science+Business Media, LLC 2010

\begin{abstract}
Early childhood teacher educators frequently enhance their teaching by reading children's books to their adult students. It is not unusual for faculty outside of early childhood to question devoting precious class time to readalouds which they may consider a curious, if not frivolous, instructional strategy. Quality children's literature can, however, enhance students' experiences in the college classroom, contribute to their understanding of course content, promote their personal growth and self-understanding, increase their appreciation for quality children's literature, and enhance their ability to integrate storybooks into their own teaching. Children's books often capture a child's point of view. They have the potential to provide historical or cultural perspectives on children and families. They also can lead to the examination of universal truths and can facilitate the discussion of sensitive or emotional issues A list of books with suggested uses is included.
\end{abstract}

Keywords Early childhood teacher education . Children's literature · Preservice teachers $\cdot$ Child development

N. K. Freeman $(\bowtie)$

USC Child Development and Research Center, University of South Carolina, USC CDRC Rm 225, 1530 Wheat Street, Columbia, SC 29201, USA

e-mail: nfreeman@sc.edu

S. Feeney

University of Hawaii, Portland, OR, USA

e-mail: feeney@hawaii.edu

E. Moravcik

Honolulu Community College, Honolulu, HI, USA

e-mail: moravcik@hawaii.edu
Do you love stories? Like most early childhood educators so do we. We regularly read children's books to adults as part of the courses we teach, as well as at conference and in-service presentations. We have used picture books effectively with teachers at every stage of their professional development: beginning students who are being introduced to the profession, student teachers immersed in the everyday life of classrooms, and practicing teachers in the midst of their teaching careers. We have found the adult learners we work with love to be read to, and report that children's books make meaningful and engaging contributions to their professional development. This enthusiastic reception to our reading makes it clear to us that many excellent children's books succeed with multiple audiences, the children for whom they were written as well as adults.

When we have made conference presentations describing our success using children's books when teaching adults we have discovered that we are not alone. Early childhood teacher educators often incorporate storybooks when they teach adults. One explanation for their attraction to children's books may be that their work with children has demonstrated to them the power of quality children's literature. We have also observed that reading children's books aloud to adult students sometimes attracts curious stares or criticism from colleagues, even within colleges of education. They question our devoting precious class time to reading aloud which they consider a peculiar, if not frivolous, instructional strategy.

In this guest editorial we present our rationale for using children's literature with adult learners and summarize feedback we have received corroborating the contributions children's books have made to our teaching. We also identify some books we have used effectively with adult learners. It is our hope that teacher educators who use children's literature with adults will find this discussion a 
re-affirming rationale if their use of children's books has been questioned, and that those who have not experimented with incorporating children's literature into their teaching may be inspired to try enjoying a good story with their college students.

\section{Using Children's Books When Teaching Adults}

Our review of the literature revealed four purposes for the incorporation of children's literature into pre-service and in-service teachers' coursework. The reason that was most frequently mentioned was to enhance students' cross-cultural competence. This effort was in response to the persistent mismatch between the teaching workforce, which is estimated to be $87 \%$ White, and the schools novice teachers are most likely to enter, where over $37 \%$ of the students are "culturally, linguistically, and ethnically different from the dominant U.S. culture" (Escamilla and Nathenson-Mejia 2003, p. 238).

The second purpose involved using children's literature to help prepare teachers to work in inclusive classrooms. These efforts were designed to help preservice teachers realize "the importance of being sensitive to those issues that are part of the lives of individuals with disabilities" (Kurtss and Gavigan 2008, p. 28) and have helped their students "begin to move beyond sympathy for individuals with disabilities and recognize their strengths" (p. 26).

A third reason reported for using children's books with preservice teachers was to prepare students to work with children and families going through divorce (Kramer 1996). A description of these efforts indicated teacher educators introduced their students to the use of bibliotherapy to "sensitize future teachers to the challenges faced by children and families" (p. 6).

Finally, Hansen and Zambo (2005) described the fourth purpose for using children's picture books which was to supplement the required textbook in a child development course. They used quality children's literature to "introduce theories, help students understand vocabulary and concepts, and to encourage students to make connections between everyday experiences with children and concepts" (p. 41). In this instance children's literature was used to help students apply theories to characters in children's books and, by extension, to the children they knew.

These examples put the spotlight on a number of contributions quality children's literature can make to teacher educators' efforts to prepare informed, reflective, and effective teachers. We have identified several additional benefits to the well-thought-out use of children's books with teachers and prospective teachers.

\section{Why We Use Children's Literature When We Teach Adults}

Our enthusiasm for using children's picture books in our teaching grew naturally from our appreciation for a good story. It meshes with our goals for our own teaching as well as the goals we have for our students. How could we not share something we care so passionately about? We want our students to know and use good children's literature. We want them to understand childhood and to be sensitive to the interests, enthusiasms, fears, and delights of children. We have identified these four ways our students benefit from our inclusion of children's literature in our teaching.

First, reading picture books aloud enhances students' experiences in the college classroom. It helps to create a nurturing and encouraging learning environment and contributes to the creation of classroom community. Additionally, it often serves as a positive, motivating experience in a higher-education setting that is all-too-often a fastpaced, high-pressure environment.

Second, sharing quality children's literature enhances students' learning about children and childhood. Good books have a capacity to capture a child's viewpoint, experience, or sense of wonder. Adult students also benefit from experiencing first-hand how picture books can effectively use images, words, and rhythms to tap into their own, and their students' multiple intelligences. Additionally, some books give us the opportunity to provide an historical perspective or cultural lens for understanding children and childhood. Books chosen to highlight historical or cultural perspectives can illustrate differences while serving as a springboard for examining universal truths about human nature, childhood, parenting, teaching, and learning. When used in this way, children's literature serves as an accessible vehicle for raising difficult or sensitive issues and provides a safe space to address some of the important and potentially emotional issues that teachers of young children encounter in their work.

A third reason we include children's literature in our early childhood courses is because the practice increases students' knowledge of good literature; adds to their repertoire of favorite titles, authors, and illustrators; and models effective strategies for sharing literature with children. In fact, we have found that students invariably discover new favorites in our classes and often are motivated to learn more about the books, authors, and illustrators we share. We are intentional about preparing for reading and take care to model effective techniques for using a variety of genres and formats, including big books, that introduce, enrich, or summarize class content. One of our goals is to help students develop their skills in effectively sharing literature with children.

Finally, children's books also contribute to our adult students' personal growth and self understanding. The right 
book can broaden their horizons, bring rich memories to mind, and lead to "aha" insights that give them emotional connections to particular course content. We have observed that by increasing students' knowledge of, and appreciation for, children's literature we are helping them come to appreciate the timeless appeal of the classics, the "read it again" draw of well wrought literature - an antidote to the notion that children's books are simply "cute" diversions for circle time. By helping them see the beauty and wisdom in children's books we are also, by extension, enhancing their appreciation and enjoyment of all literature. They are having opportunities to experience the delights of wellcrafted words and images that can evoke emotional, aesthetic and moral responses. It is our hope that our students will get into the habit of turning to literature to refresh and renew themselves as well as children, and that their teaching is richer because of having been in our classes.

\section{Soliciting Students' Voices}

Reading children's picture books to students enrolled in early childhood teacher preparation courses has always seemed worthwhile, but reading out loud takes a significant amount of class time. While we were fairly certain that reading children's books was beneficial, we sought students' feedback to see if they agreed and to learn about their perspectives. Their responses to an anonymous survey indicated that they too believed that quality children's literature enhanced their experiences in our classrooms.

These comments are typical responses describing how sharing children's books in class improved adult students' overall experience:

- “I think it is a wonderful idea to read children's books to adults. You get such a different perspective."

- "I love it. It really helps and I enjoy being read to. Taking it out of the curriculum would be a mistake."

Survey respondents also frequently described how the books read in class helped them master the course content while encouraging class discussions:

- "The books helped aid class discussions and clarify topics."

- "The choice of books read in class was helpful with tying in the information that was being taught in lecture."

- "It was helpful to see a book about what we were learning. It's a nice visual to go with the lecture."

- "Not only did [read-alouds] give me titles to add to my library, but they help me understand the material in a different way than a textbook."
- "The books were great examples of how we can apply what we learned in class in the classroom."

- "The literature made the class more interesting and I love the discussions."

Students indicated that children's books also helped them develop a richer understanding of children and childhood:

- "[Reading books in class] allowed me to more clearly understand the way in which many young children perceive the world."

- "Sharing the literature helped me to get a visual understanding of the information discussed."

- "I really enjoyed the children's literature we used in class because it gave specific examples that I believe will help me."

They also expressed their appreciation for the contributions quality picture books can make to the curriculum and were enthusiastic about the opportunity to increase their repertoire of quality children's literature:

- "I feel that the more literature the better, especially at this time in the education program [most students are sophomores]. Students need to start getting introduced to a lot of books. One or two should be read a week."

- "I think now I feel I am more able to connect stories to life. Before I would just read to read or see pictures, now I know how to read to not just show children's books, but reflect also."

- "It made me realize there is more to children's literature than cute and fun books. Most have an underlying meaning..."

Other comments indicated that students were reaping additional benefits we had hoped would result from the time we spent on reading children's books in class. Some students indicated the experience helped them see how books illustrate varied instructional strategies; others indicated they planned to include some of these books in their classroom libraries. A number of students saw how they could emulate our use of quality literature in their own classrooms.

A final comment summed up most students' overall opinion of their experiences with hearing quality children's books in their post-secondary classrooms, "You don't have to be young to enjoy children's literature."

\section{Conclusion}

We have long believed time spent reading children's picture books to students enrolled in early childhood courses was an effective way to enrich our teaching and students' experiences and expand their learning. We have now heard 
the voices of some students indicating they also view this practice as beneficial and a worthwhile enhancement to lectures and other class presentations. We hope the rationale we have provided, along with the titles we suggest below, will encourage you to read to your adult students and to explain to any skeptics why you have included these carefully selected children's books in your teaching repertoire.

\section{Suggested Books for Use in Early Childhood Teacher Education}

These are some of the books we have found to be effective teaching tools. You will probably find that this list includes titles and authors that are old friends. Perhaps you will see a new way to use them in your teaching by thinking about how they can illustrate child development, curriculum, working with families, or another topic you cover when you teach. Other books are likely to be unfamiliar. We hope this list will inspire you to explore some new titles and think about how they can enrich your work with preservice and in-service teachers of young children.

\section{The Early Childhood Profession}

These titles spotlight the value of sticking to a hard task, address the role of the community/society in early childhood education, and illustrate the historical roots of early childhood education:

\begin{tabular}{ll}
\hline Courage & Bernard Waber \\
It Takes a Village & Jane Cowen-Fletcher \\
Good Night Moon \& The Noisy Books & Margaret Wise Brown
\end{tabular}

\section{Teachers and Teaching}

These are some of the books we have found effective in illustrating the impact of teachers, the importance of nurturing children, the value of reflective practice as you create your own teaching style, and the importance of accepting individual differences:

\begin{tabular}{ll}
\hline Lilly's Purple Plastic Purse & Kevin Henkes \\
Miss Nelson is Missing & Harry Allard \\
Mrs. Spitzer's Garden & Edith Patou \\
Whoever You Are & Mem Fox \\
Everybody Needs a Rock & Byrd Baylor \\
\hline
\end{tabular}

\section{Child Development}

Early childhood educators need to be experts in child development. These titles provide glimpses of particular aspects of development in ways that bring sometimesabstract ideas to life:

\begin{tabular}{ll}
\hline Mama Do You Love Me? & Barbara M. Joose \\
Papa Do You Love Me? & Barbara M. Joose \\
Runaway Bunny & Margaret Wise Brown \\
Yesterday I Had the Blues & Jeron Ashford Frame \\
Bread and Jam for Frances & Russell Hoban \\
Wemberly Worried & Kevin Henkes \\
There's a Nightmare in my Closet & Mercer Mayer \\
Harry and the Terrible Whatzit & Dick Gackenbach \\
Ira Sleeps Over & Bernard Waber \\
\hline
\end{tabular}

\section{Relationships and Guidance}

One of the most important things children learn from early group experiences is how to get along with their classmates. These titles remind adults of some of the struggles and challenges children face as they form friendships and negotiate the inevitable bumps in the road they encounter along the way:

\begin{tabular}{ll}
\hline Noisy Nora & Rosemary Wells \\
Owen & Kevin Henkes \\
When Sophie Gets Angry & Rachel Vail \\
Hooway for Wodney Wat & Helen Lester \\
The Cardboard Piano & Lynne Rae Perkins \\
\hline
\end{tabular}

\section{Observation and Assessment}

Keen observation skills can help early childhood educators resist the tremendous pressure they face to assess children in inappropriate ways. Some of these titles highlight the importance of careful observation and others illustrate some of the dangers of inappropriate assessments:

\begin{tabular}{ll}
\hline Seven Blind Mice & Ed Young \\
The Trek & Anne Jonas \\
The Other Way to Listen & Byrd Baylor \\
All the Colors of the Earth & Sheila Hamanaka \\
First Grade Takes a Test & Miriam Cohen \\
Hooray for Diffendoofer Day & Dr. Seuss \\
\hline
\end{tabular}




\section{Practicum/Lab}

These titles remind the reader of the fears and reluctance children sometimes bring to the first days of school:

\begin{tabular}{ll}
\hline Timothy Goes to School & Rosemary Wells \\
Will I Have a Friend? & Miriam Cohen \\
You Go Away & Dorothy Corey \\
Anna's Goodbye Apron & Julie Brillhart \\
\hline
\end{tabular}

\section{Curriculum}

Early childhood educators have the opportunity to turn everyday events into meaningful curriculum for young children. These titles provide inspiration and have the potential to launch hands-on learning across the curriculum:

\begin{tabular}{ll}
\hline The Trek & Ann Jonas \\
Muddigush & Kimberly Knutson \\
The Art Lesson & Tomie dePaola \\
Giving Thanks & Jake Swamp \\
An Egg Is An Egg & Nicki Weiss \\
Whoever You Are & Mem Fox \\
Bread, Bread, Bread & Ann Morris \\
Bunny Cakes & Rosemary Wells \\
Round Trip & Ann Jonas \\
The Doorbell Rang & Pat Hutchins \\
Squish! A Wetlands Walk & Nancy Luenn \\
Owl Moon & Jane Yolen \\
\hline
\end{tabular}

\section{Working with Families}

Developing positive working relationships with children's families is an important part of an early childhood educator's responsibilities. Some of these books celebrate parenthood, others illustrate diverse families, and there are titles here that are reminders of the challenges families face on a day-to-day basis:

\begin{tabular}{ll}
\hline Our Granny & Margaret Wild \\
Harriet, You'll Drive Me Wild & Mem Fox \\
Oh My Baby, Little One & Kathi Appelt \\
Everywhere Babies & Susan Meyers \\
\hline
\end{tabular}

\section{Children with Special Needs}

Children with special needs are children first, with their unique needs, interests, and abilities. These titles portray children with special needs in a positive light. The focus is on their gifts and abilities.

\begin{tabular}{ll}
\hline Someone Special Just Like You & Fran Oritz \\
Friends in the Park & Rochelle Bunnett \\
Where's Chimpy? & Berniece Rabe \\
Leo the Late Bloomer & Robert Kraus \\
\hline
\end{tabular}

\section{References}

Escamilla, K., \& Nathenson-Mejia, S. (2003). Preparing culturally responsive teachers: Using Latino children's literature in teacher education. Equity \& Excellence in Education, 36, 238-248.

Hansen, C. C., \& Zambo, D. (2005). Piaget, meet Lilly: Understanding child development through picture book characters. Early Childhood Education Journal, 33(1), 39-45.

Kramer, P. A. (1996). Preparing teachers to help children and families of divorce. ERIC document ED, 393, 936.

Kurtss, S. A., \& Gavigan, K. W. (2008). Understanding (dis)abilities through children's literature. Education Libraries, 31(1), 23-31. 